and extensive changes or reappraisal are being recommended by the Committee.

The names and qualifications of members, and the Chairman should be in a public document. The Committee should have a quorum and this should include two lay members. Decisions should be reached by a simple majority of those present and voting. Decisions should be notified in writing to the applicant.

When an adverse decision is made, it should be accompanied by advice to the applicant, who should be able to submit revised proposals. If the applicant wishes, he should be able to appear before the Committee to discuss relevant issues. This discussion should be carried out in a way that is educative.

It is not easy for Ethics of Research Committees to monitor the outcome of their work. If it is difficult to review every project in detail, a minimum requirement is that reports be obtained of any accidents or adverse reactions, and of any complaints made about research. Projects that appear to the Committee to raise difficult issues may require more detailed follow-up enquiry, and reporting to the parent body.

The Committee has no power to prevent research being carried out, but if it learns that its advice is ignored, or investigators are failing to refer research to it, the Chairman should report this to the parent Health Authority.

The Committee should report annually in writing to the Health Authority to which they are responsible. The form of the report will be decided by that Authority but should generally contain a list of members, numbers of meetings (perhaps with numbers of members attending each), a note of any issues of general importance, and a list of the titles of the research projects considered, with the decisions reached.

\section{Responsibility in law of Ethics of Research Committees}

The Royal College of Physicians has pointed out that the members of Ethics of Research Committees could be regarded as having responsibilities in law.
This is a strong reason for ensuring that Committees are properly constituted, and carry out their business thoroughly. It also indicates that the appointing Authority should, in the letter of appointment to Committee members, formally agree to indemnify them for any loss (including the costs of legal representation) arising out of their function as members of the Committee.

June 1989

\section{References}

BROOKE, H. (1986) Consent to treatment or research: the incompetent patient. In: Consent and the Incompetent Patient: Ethics, Law and Medicine. (Eds S. R. Hirsch and J. Harris). London: Gaskell (Royal College of Psychiatrists) pp. 9-21.

Nicholson, R. H. (ed) (1986) Medical Research with Children: Ethics, Law and Practice. Oxford University Press.

Relevant Reports

a. Royal College of Physicians:

1984 Guidelines on the Practice of Ethical Committees in Medical Research.

1986 The Relationship between Physicians and the Pharmaceutical Industry.

1986 Research in Healthy Volunteers.

1990 Guidelines on the Practice of Ethical Committees in Research involving Human Subjects (second edition).

b. Medical Research Council:

1962/3 Responsibility in Investigations on Human Subjects.

c. British Psychological Society:

1978 Ethical Principles for Research with Human Subjects.

d. Royal College of Nursing:

1977 Ethics Related to Research in Nursing.

e. Royal College of Psychiatrists (Gaskell Publications):

1988 Hirsch, S. R. \& Harris, J. (eds) Consent and the Incompetent Patient. Ethics, Law and Medicine.

f. Institute of Medical Ethics:

1986 Nicholson, R. H. (ed). Medical Research with Children: Ethics, Law and Practice. Oxford University Press.

\title{
Autumn Quarterly Meeting, 1989
}

The Autumn Quarterly Meeting was held at Kensington Town Hall, London on 25 and 26 October 1989 under the Presidency of Dr J. L. T. Birley.

\section{Business Meeting}

The business meeting was held on 26 October 1989 , attended by 37 Members of the College. 


\section{Minutes}

The minutes of the Spring Quarterly Meeting held at the Clarendon Lecture Theatre, Medical School, University of Leeds on 5 April 1989, were approved and signed.

\section{Registrar's report}

The College has been occupied over the summer months with producing a number of documents in response to requests from both inside and outside the College.

The Spokes Inquiry was convened to look into the care and after-care of Sharon Campbell following the tragic murder of a social worker, Elizabeth Schwarz. The Inquiry recommended that the College be invited to publish a document on good practice for the discharge and after-care of patients discharged from in-patient psychiatric treatment. A document on good medical practice has been produced by a working party. It was then circulated within the College and the helpful suggestions from the sections and groups incorporated into the final version. This document will now be circulated by the Department of Health to the professional bodies representing the different members of multidisciplinary teams including nursing, social work, psychology, occupational therapy and pharmacy. It has already been sent to general practitioners.

The Mental Health Act Commission in its Second Biennial Report referred to a list of issues upon which the Commission would be focusing over the coming two years. The following two Working Groups were convened to prepare the College's view on these concerns.

A working group representing the sections for mental handicap, old age psychiatry and child and adolescent psychiatry was invited by the Executive and Finance Committee to prepare a College policy statement on the treatment of patients incapable of giving consent and the restraint and detention of patients who are not subject to compulsory orders. The report of this working group has just been approved by Council.

Another working party was convened to produce the Guidelines to Good Practice in the Use of Behavioural Treatments. These had been considered in the past as a controversial issue. Their report is now complete.

A Special Committee has reported on Confidentiality. It is a complex issue and the working party were occupied on the production of this report for over two years. With minor amendments Council have accepted their report as a position statement.

All these reports were accepted by Council on 23 October 1989 with minor amendments and will shortly be available at a low cost to members of the College.
The College continues to maintain and express its concern about the implementation of the White Paper on the future of the National Health Service. There has been insufficient media attention to the position of the Royal Colleges concerning the welfare of patients, education of both under-graduate and post-graduate doctors and of research issues.

The Government has at last produced its response to the Griffiths Report on Community Care. This was studied by a working group of the College who were particularly concerned about the 'ring fencing' of money currently used for residential care. The group were also concerned for the on-going medical and social care of the severely mentally ill.

The exceptional summer produced some difficulties for the new part of the College building, on the fourth floor, which was opened just a year ago. It became excessively hot and urgent measures had to be taken to make it bearable for staff to work there.

We look forward to planning for the 150th Anniversary of the origins of the College which will occur in 1991. The College will be organising special publications and events of both a scientific and social nature.

Dr ANn Gath Registrar

\section{Business Meeting Notes}

The President reported that Council had supported the idea of a preliminary College visit to South Africa to collect information on current psychiatric practice with regard in particular to aspects in which the College would wish to see an improvement in two years' time. Three members of the College would be involved in the initial visit planned early in the New Year. The President would report further at the Winter Quarterly Meeting in January.

The President informed the meeting that a press conference had taken place at the College following the re-admission of the All Union Association of Soviet Psychiatrists and Neurologists to the World Psychiatric Association. A site visit by the WPA Review Committee will be made within one year and if the report indicates that political abuse is continuing, a General Assembly Special Meeting will be convened to consider suspension of membership.

\section{Eli Lilly Lecture}

Professor George Winokur MD of the Department of Psychiatry, University of Iowa, will be delivering the 1990 Eli Lilly Lecture during the Winter Quarterly Meeting. Professor Winokur will be talking on 'Schizoaffective Disorder Revisited' at $2.00 \mathrm{pm}$ on Tuesday, 23 January 1990 in the Barnes Hall, Royal Society of Medicine, London. All Members are welcome to attend and details will have been circulated with papers for the Winter Quarterly Meeting. 